\title{
Pengelompokan Kabupaten/Kota di Pulau Jawa Berdasarkan Kondisi Sosial Ekonomi Sebelum dan Setelah Memasuki Pandemi COVID-19 Penerapan Metode Cluster Ensemble
}

\author{
(Grouping of Regencies/Cities in Java Island Based on Socioeconomic Condition \\ Before and After Into the COVID-19 Pandemic) \\ Shela Yulfia Hadist ${ }^{1 *}$, Agung Priyo Utomo ${ }^{2}$ \\ 1,2 Politeknik Statistika STIS \\ Jalan Otto Iskandardinata No. 64C Jakarta Timur

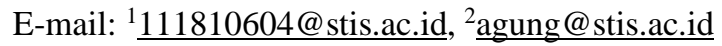

\begin{abstract}
ABSTRAK
Prospek ekonomi Indonesia melemah secara signifikan dengan adanya pandemi COVID-19. Struktur perekonomian Indonesia secara spasial pada tahun 2020 didominasi oleh kelompok provinsi di Pulau Jawa yang memberikan kontribusi terhadap PDB sebesar 58,75 persen. Pandemi COVID-19 memiliki dampak sosial ekonomi terbesar di wilayah yang padat penduduk dikarenakan pembatasan sosial, termasuk Pulau Jawa sebagai pusat perekonomian Indonesia. Hal ini dapat mengindikasikan apabila perekonomian Pulau Jawa terkontraksi, maka perekonomian Indonesia ikut terkontraksi. Penelitian ini bertujuan untuk menganalisis kondisi sosial ekonomi di Pulau Jawa sebelum dan setelah memasuki pandemi COVID-19 dan mengelompokkan kabupaten/kota di Pulau Jawa berdasarkan kondisi sosial ekonomi melalui variabel Pertumbuhan Ekonomi, Tingkat Pengangguran Terbuka, jumlah angkatan kerja, jumlah sektor unggulan, pengeluaran per kapita, dan persentase penduduk miskin, serta membandingkannya ketika sebelum dan setelah memasuki pandemi COVID-19 dengan menggunakan metode Cluster Ensemble. Hasil yang didapatkan menunjukkan bahwa secara rata-rata terjadi penurunan pertumbuhan ekonomi dan jumlah sektor unggulan, serta peningkatan TPT, jumlah angkatan kerja, penduduk miskin, dan pengeluaran per kapita di Pulau Jawa setelah memasuki pandemi COVID-19. Dari 3 klaster yang terbentuk pada tahun 2019 dan 5 klaster pada tahun 2020, didapat bahwa secara umum pengelompokan tiap klaster tidak jauh berbeda, namun terdapat beberapa perbedaan karakteristik dan anggota klaster.
\end{abstract}

Kata kunci: sosial ekonomi, sektor unggulan, Pulau Jawa, COVID-19, Cluster Ensemble

\begin{abstract}
Indonesia's economic outlook has turned significantly weaken due to the declaration of the COVID-19 pandemic. Indonesia's economic structure in 2020 spacially dominated by the Java group provinces, contributing 58.75 percent to the national total GDP. COVID-19 pandemic has had the greatest socio-economic impact, particularly on densely populated areas due to the incessant of social restrictions, including the island of Java, the center of the Indonesian economy. This indicated that if the economy of Java is contracted, the Indonesian economy will also be contracted. This study aims to analyze the socio-economic description of groupings economic in Java before and after into the COVID19 pandemic based on the variables of economic growth, open unemployment rate, number of workforces, number of leading sectors, per capita expenditure, and percentage of poor people, and compare it before and after entering pandemic using the Cluster Ensemble method. The results obtained indicate that there are economic growth and the number of leading sectors in Java are deteriorating. This study also found that the number of unemployment rate, workforces, poor people, and per capita expenditure, is increasing after facing the COVID-19 pandemic. In the 3 clusters formed in 2019 and 5 clusters formed in 2020, it is generally found that the grouping of each cluster was not significantly different, but there were some differences in the characteristics and members of the cluster.
\end{abstract}

Keywords: socioeconomic, leading sectors, Java Island, COVID-19, Cluster Ensemble

\section{PENDAHULUAN}

Salah satu fenomena yang melanda dunia pada akhir tahun 2019, secara khusus pada Maret 2020 di Indonesia, dan memberikan pengaruh terhadap perekonomian baik dalam jangka pendek maupun jangka panjang adalah pandemi COVID-19. Thaariq et al (2020) menyatakan bahwa pandemi COVID-19 memberikan dampak yang cukup besar bagi masyarakat, baik dari sisi kesehatan, sosial, dan ekonomi, termasuk peningkatan jumlah penduduk miskin. Indonesia masih rapuh dalam menghadapi perekonomian pada masa pandemi COVID-19 (Olivia, Gibson, dan Nasrudin, 2020). 


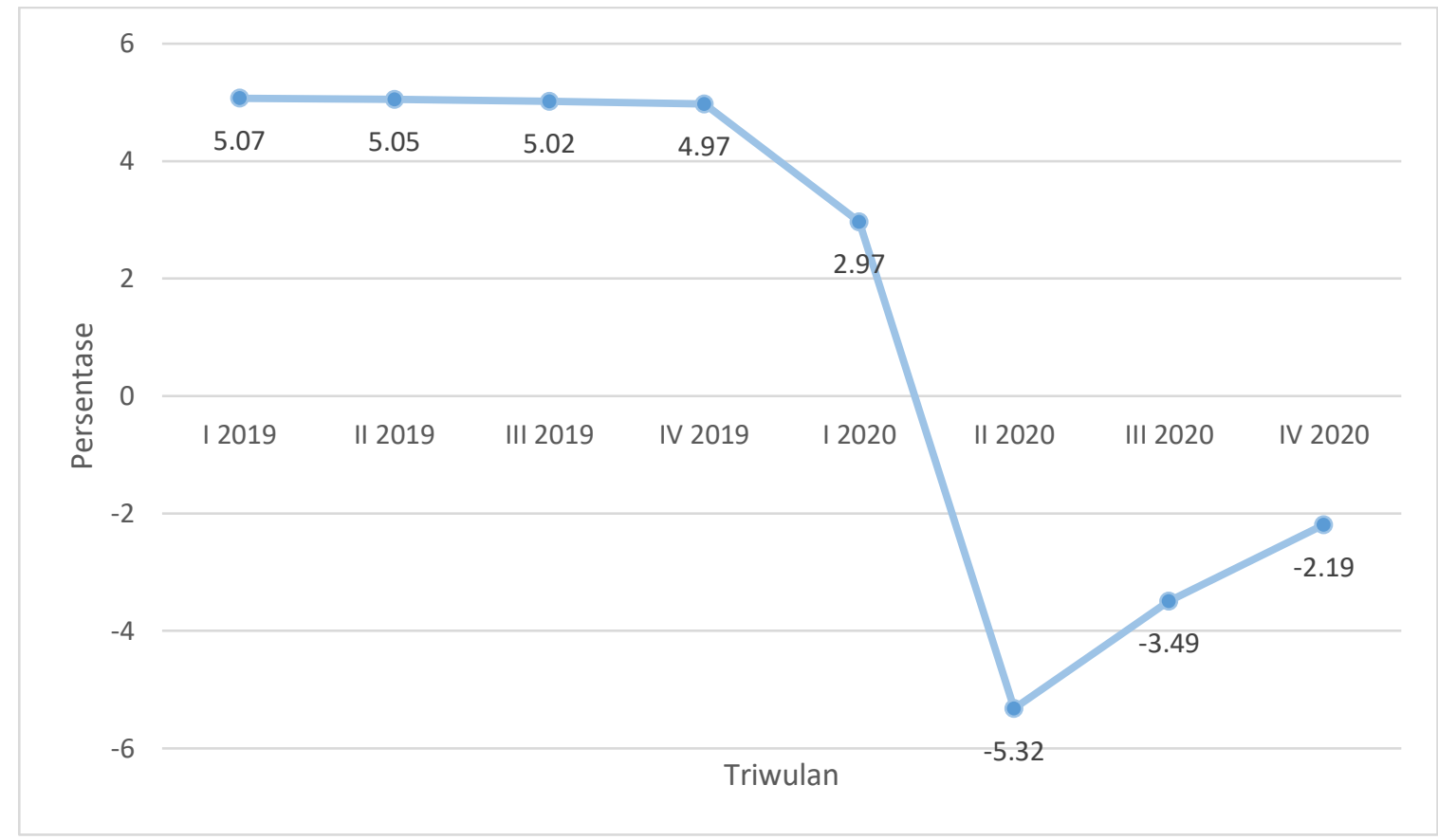

Sumber: Badan Pusat Statistik

Gambar 1. Laju Pertumbuhan PDB Triwulan I 2019-Triwulan IV 2020

Berdasarkan Gambar 1, pertumbuhan ekonomi pada tahun 2020 mengalami penurunan yang cukup signifikan dan menyentuh angka negatif. Hampir seluruh kontribusi sektor produksi menurun mulai dari triwulan I tahun 2020 yang ditandai dengan menurunnya kontribusi beberapa sektor Pertumbuhan Domestik Bruto (PDB). Dalam laporan enam bulanan Prospek Perkonomian Indonesia (Indonesia Economic Prospects, IEP) yang diterbitkan oleh Bank Dunia, didapat hampir seperempat dari responden survei telah berhenti bekerja pada akhir bulan Mei dan sekitar dua pertiga responden survei yang masih bekerja mengalami penurunan penghasilan. Jika tidak ditanggulangi, hal ini akan berpengaruh pada menurunnya penghasilan rumah tangga secara agregat antara 5 hingga 7 persen. Bank Dunia juga memperkirakan 2,6-3,6 juta penduduk Indonesia akan kehilangan pekerjaan atau menjadi tidak aktif (Bank Dunia, 2020).



(a) Banten

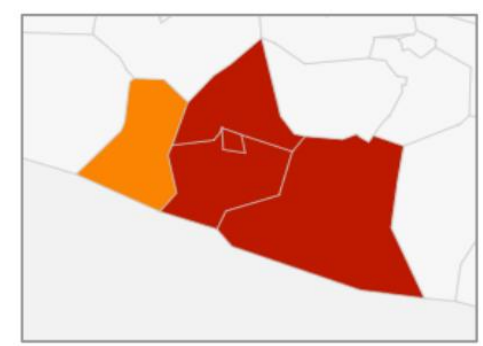

(d) D. I. Yogyakarta

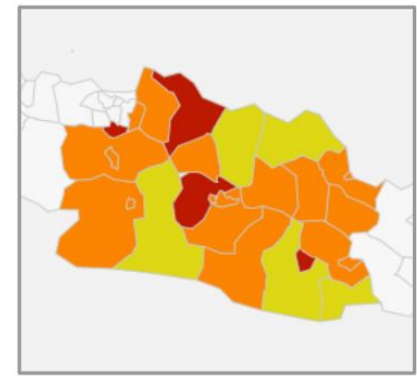

(b) Jawa Barat

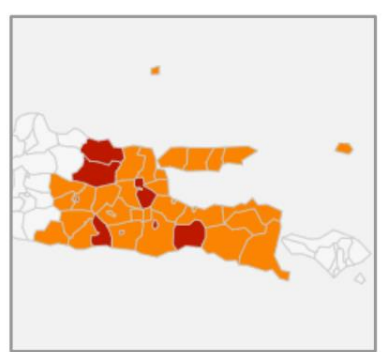

(e) Jawa Timur

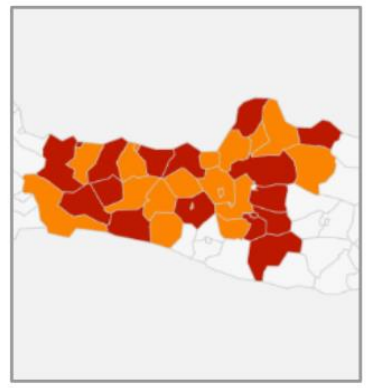

(c) Jawa Tengah

Keterangan:

Risiko rendah

Risiko sedang

Risiko tinggi

Sumber: Satuan Petugas Penanganan COVID-19

Gambar 2. Sebaran Zonasi Risiko COVID-19 Tiap Kabupaten/Kota di Pulau Jawa 
Menurut Gugus Tugas Penanganan Covid-19 (2020), per 13 Desember 2020, Pulau Jawa masih menjadi episentrum Covid-19 yang menyumbang 60.74 persen kasus kumulatif secara nasional. Kementerian Kesehatan melalui Satgas Penanganan COVID-19 melakukan penghitungan zonasi risiko berdasarkan 3 indikator utama, yaitu epidemiologi, surveilans kesehatan masyarakat, dan pelayanan kesehatan. Dari Gambar 2, didapat bahwa pada akhir tahun 2020 sebagian besar kabupaten/kota di Pulau Jawa termasuk dalam zonasi risiko sedang dan tinggi. Hanya ada satu provinsi yang beberapa wilayahnya masih memiliki daerah risiko rendah, yaitu Provinsi Jawa Barat. Kebijakan pemerintah untuk menerapkan Pembatasan Sosial Berskala Besar (PSBB) di sejumlah daerah — terutama di Pulau Jawa yang merupakan pusat dari perekonomian Indonesiamembuat aktivitas ekonomi masyarakat terbatas. Menurut Modjo (2020), pemberlakuan PSBB menjadi kontributor utama penurunan PDRB dikarenakan penurunan aktivitas sosial ekonomi masyarakat.

Kondisi perekonomian pada tahun 2020 baik secara global maupun nasional cenderung mengalami penurunan jika dibandingkan dengan tahun sebelumnya. Pandemi COVID-19 yang melanda Indonesia mulai awal Maret 2020 memberikan dampak negatif yang signifikan terhadap pertumbuhan ekonomi. Pulau Jawa merupakan pusat dalam perekonomian Indonesia karena memberi lebih dari setengah kontribusi dari total PDB Indonesia. Modjo (2020) dalam penelitiannya menyatakan bahwa pandemi Covid-19 memiliki dampak sosial ekonomi terbesar di wilayah yang memiliki banyak daerah urban padat penduduk, dan diproyeksikan penurunan PDRB terbesar yang paling terdampak adalah provinsi-provinsi di Pulau Jawa. Menurut Hair (2019), analisis klaster dapat digunakan untuk mengeksplorasi serta mengembangkan gambaran permasalahan berdasarkan karakteristik data. Stukalo dan Simakhova (2018) dalam penelitiannya menyebutkan bahwa clustering dari variabel sosial ekonomi dapat menunjukkan kemungkinan perkembangan sosial dari suatu negara dalam rentang waktu tertentu. Oleh karena itu, penelitian ini bertujuan untuk membandingkan analisis pengelompokan kabupaten/kota di Pulau Jawa berdasarkan kondisi sosial ekonomi saat sebelum dan setelah memasuki pandemi COVID-19 dengan menggunakan metode Cluster Ensemble. Dengan melakukan perbandingan pengelompokan antara tahun 2019 dan 2020, dapat dilihat perubahan kelompok serta karakteristik.

\section{METODE}

Penelitian ini meliputi seluruh kabupaten/kota yang ada di Pulau Jawa, kecuali provinsi DKI Jakarta. Data yang digunakan merupakan data sekunder dari Publikasi Daerah Dalam Angka Badan Pusat Statistik dari 5 provinsi, yaitu Provinsi Banten, Jawa Barat, Jawa Tengah, D. I. Yogyakarta, dan Jawa Timur. Jenis data yang digunakan adalah cross section sebanyak 113 unit analisis yang meliputi 84 kabupaten dan 29 kota. Variabel yang digunakan meliputi pertumbuhan ekonomi, Tingkat Pengangguran Terbuka, jumlah angkatan kerja, jumlah sektor basis, rata-rata pengeluaran per kapita, dan persentase penduduk miskin. Periode data yang diambil dalam penelitian ini adalah pada tahun 2019 dan tahun 2020. Penelitian ini memanfaatkan package Cluster Ensemble yang sudah tersedia pada program $\mathrm{R}$ yaitu diceR.

\section{Analisis Deskriptif}

Analisis deskriptif digunakan untuk mendeskripsikan hasil dari penelitian dan menyajikan data secara lebih informatif berdasarkan variabel-variabel yang telah disusun. Dalam penelitian ini, analisis deskriptif berfungsi untuk mengolah variabel jumlah sektor unggulan menggunakan Location Quotients dan Model Rasio Pertumbuhan, menggambarkan variabel sosial ekonomi secara keseluruhan dan tiap provinsi, perbandingan variabel sosial ekonomi tahun 2019 dan 2020, dan karakteristik hasil pengelompokan tiap klaster.

\section{Analisis Location Quotient (LQ)}

Location quotients (LQ) merupakan perbandingan ekonomi sektor lapangan usaha regional dengan ekonomi nasional (Glasson dan Marshall, 2007). Metode ini digunakan untuk mengidentifikasi sektor ekonomi potensial yang menjadi unggulan yang dapat dikembangkan di suatu wilayah dan mengidentifikasi keunggulan komparatifnya, yang dirumuskan sebagai berikut:

$$
L Q=\frac{e_{i} / e}{E_{i} / E}
$$

Keterangan:

LQ: Nilai Location Quotient sektor i di wilayah regional

$e_{i}$ : Nilai tambah PDRB ADHK sektor i di kabupaten/kota analisis

E: Total PDRB ADHK di kabupaten/kota analisis 
$E_{i}$ : Nilai tambah PDRB ADHK sektor i provinsi analisis

E: Total PDRB ADHK di provinsi analisis

\section{Analisis Model Rasio Pertumbuhan (MRP)}

Analisis Model Rasio Pertumbuhan (MRP) merupakan alat analisis yang digunakan dalam penentuan deskripsi kegiatan ekonomi perencanaan wilayah dan kota yang lebih menekankan pada kriteria pertumbuhan. Analisis MRP dibagi atas 2 yaitu Rasio Pertumbuhan Wilayah Referensi $\left(\mathrm{RP}_{\mathrm{r}}\right)$ dan Rasio Pertumbuhan Wilayah Studi $\left(\mathrm{RP}_{\mathrm{s}}\right)$. Namun, yang digunakan dalam penelitian ini hanya Rasio Pertumbuhan Wilayah Studi $\left(\mathrm{RP}_{\mathrm{s}}\right)$ yang merupakan perbandingan antara laju pertumbuhan sektor ekonomi $i$ wilayah studi dengan laju pertumbuhan sektor ekonomi $i$ wilayah referensi. Dirumuskan sebagai berikut :

$$
R P_{S}=\frac{\Delta E_{i j} / E_{i j,(t-1)}}{\Delta E_{i R} / E_{i R,(t-1)}}
$$

Keterangan:

$\Delta E_{i R}$ : Selisih antara nilai PDRB sektor $i$ akhir tahun pengamatan dan awal tahun pengamatan wilayah referensi. $\Delta E_{R}$ : Selisih nilai total PDRB akhir tahun pengamatan dan awal tahun pengamatan wilayah referensi

\section{Analisis Cluster Ensemble}

Analisis klaster digunakan untuk mengelompokkan observasi dan mengidentifikasi karakteristik tiap kelompok untuk kondisi perekonomian di 111 kabupaten/kota di Pulau Jawa. Pengelompokan dilakukan dengan menggunakan metode Cluster Ensemble. Ensemble merupakan sebuah proses penggabungan beberapa hasil simulasi menjadi satu hasil akhir tanpa mengakses data yang dianalisis (Strehl \& Ghosh, 2002). Teknik ini digunakan untuk mengatasi permasalahan randomisasi dan ketidakstabilan hasil. Implementasi teknik ini pada analisis klaster disebut Cluster Ensemble atau consensus cluster.

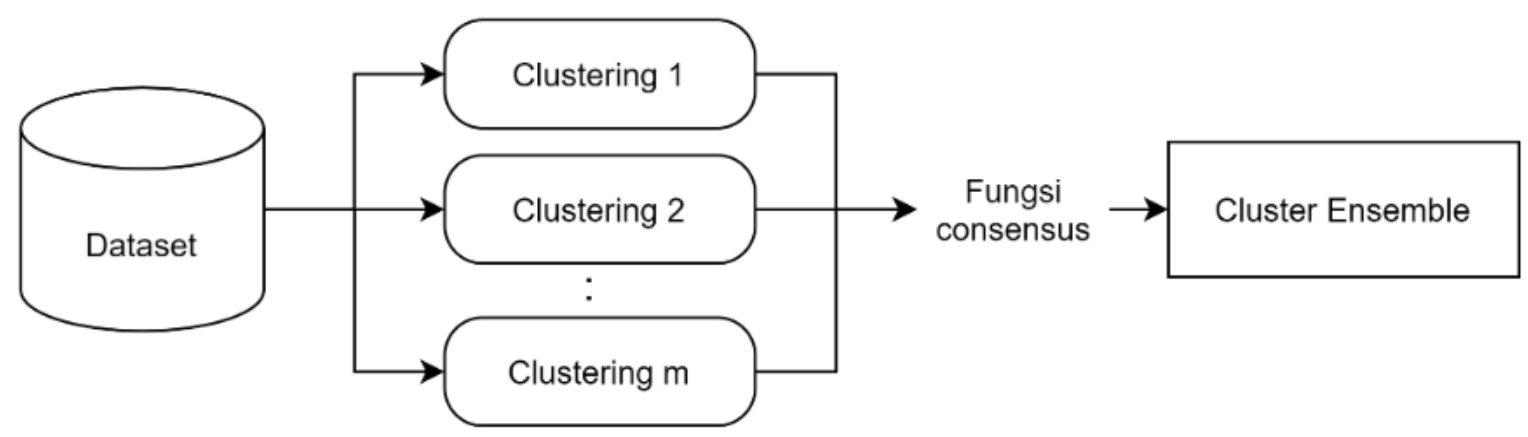

Gambar 3. Langkah Pengelompokan dengan Cluster Ensemble

Berdasarkan Gambar 3, secara umum pengelompokan observasi dengan metode Cluster Ensemble dilakukan dalam dua tahap, yaitu:

1. Membentuk anggota ensemble yang anggotanya merupakan solusi dari berbagai metode pengelompokan yang berbeda.

2. Mengombinasikan seluruh anggota ensemble untuk memperoleh satu solusi akhir yang dinamakan consensus.

Dalam Cluster Ensemble terdapat sebuah fungsi yang dinamakan fungsi consensus. Fungsi consensus didefinisikan sebagai fungsi yang memetakan sekumpulan solusi klaster menjadi solusi gabungan hingga diperoleh satu hasil pengelompokan yang stabil dan robust. Menurut Strehl dan Ghosh dalam Saeed et al (2012), algoritma consensus clustering yang berbasis grafik atau Cluster-based Similarity Partitioning Algorithm (CSPA), yang diusulkan oleh Strehl dan Gosh, merupakan salah satu fungsi consensus yang efisien. CSPA digunakan untuk mendapatkan partisi consensus dari ensemble yang dihasilkan di tahapan pembuatan partisi. Dengan menggunakan algoritma ini, pengelompokan menandakan hubungan antara objek dalam klaster yang sama dan dengan demikian dapat digunakan untuk menetapkan ukuran kesamaan berpasangan (similarity matrix). Ukuran kemiripan tersebut kemudian diinduksi dan digunakan untuk mengelompokkan kembali atau recluster observasi yang kemudian menghasilkan gabungan klaster.

Berikut merupakan tahapan analisis.

1. Memilih variabel yang akan digunakan dan mengumpulkan data untuk kedua tahun penelitian; 
2. Melakukan standardisasi data dengan mengubah seluruh data menjadi Z-score untuk kedua tahun;

3. Melakukan pemeriksaan pencilan dan multikolinieritas untuk data kedua tahun;

4. Melakukan pengelompokan dengan metode klaster gabungan, yaitu hierarki dan nonhierarki;

5. Menganalisis penggabungan dari metode terkait dengan menggunakan consensus cluster;

6. Mengelompokkan seluruh observasi dari ensemble yang terpilih;

7. Melakukan evaluasi untuk hasil pengelompokan;

8. Menentukan jumlah klaster terbaik.

\section{Indeks Evaluasi Pengelompokan}

Terdapat beberapa indeks yang digunakan untuk mengevaluasi hasil pengelompokan, yaitu indeks Davies-Bouldin (DB), Calinski Harabasz (CH), dan Xie Beni. Ketiga indeks ini digunakan guna mencakup pemilihan beberapa algoritma ensemble, yaitu hierarchical (hc), divisive analysis (diana), partition around medoids (pam), fuzzy c-means (cmeans), dan K-Means (KM).

\section{Davies-Bouldin (DB)}

Salah satu metode untuk mengevaluasi hasil klaster yang didasarkan pada nilai kohesi dan separasi adalah indeks Davies Bouldin (DB). Kohesi merupakan jumlah dari kedekatan data terhadap centroid dari klaster yang diikuti. Sedangkan, separasi merupakan jarak antar centroid dari klasternya. Indeks DB mengukur rata-rata kesamaan antara masing-masing kelompok yang paling mirip (Iam-on dan Garret, 2010).

Keterangan:

$$
D B I=\frac{1}{k} \sum_{i=1}^{k} \max _{i \neq j}(\mathrm{Ri}, \mathrm{j})
$$

$\mathrm{k}$ : jumlah klaster

$\mathrm{R}_{\mathrm{ij}}$ : rasio kohesi dan separasi

2. Calinski-Harabasz $(\mathrm{CH})$

Indeks Calinski-Harabasz $(\mathrm{CH})$ diusulkan oleh Harabasz J. dan RB Calinski. Indeks ini dapat dihitung melalui persamaan berikut.

$$
C H(K)=\frac{\frac{S S W_{i}}{k}-1}{\frac{S S B_{i, j}}{N}-k}
$$

Keterangan:

k: kelompok

$\mathrm{N}$ : objek yang dikelompokkan

SSW: sum of square within cluster

SSB: sum of square between cluster

3. Xie-Beni

Proses validasi indeks dengan Xie-Beni membandingkan rata-rata pusat klaster akhir dengan data validasi yang diperoleh dari data observasi. Indeks ini dapat dihitung melalui persamaan berikut.

$X B(c)$

$$
=\frac{\sum_{k=1}^{n} \sum_{i=1}^{c}\left(\left[\sum_{a=1}^{p}\left(X_{k a}-V_{i a}\right)^{2}\right]\left(\mu_{i k}\right)\right)}{n \cdot \min _{i, j}\left\|V_{i} V_{j}\right\|^{2}}
$$

Keterangan:

c: jumlah klaster

n: objek yang dikelompokkan

$\mu_{i k}$ : derajat keanggotaan

w: pangkat pembobot

$\operatorname{n.min}_{i, j}\left\|V_{i} V_{j}\right\|^{2}:$ jarak minimum antara pusat klaster $V_{i}$ dan $V_{j}$

\section{HASIL DAN PEMBAHASAN}

\section{Gambaran Umum Kondisi Sosial Ekonomi di Pulau Jawa Tahun 2019 dan 2020}

Sebagai pulau dengan jumlah penduduk terbesar di Indonesia, sebagian besar wilayah di Pulau Jawa memberlakukan kebijakan PSBB baik dalam skala mikro maupun zona kawasan tertentu. Pertumbuhan Ekonomi Indonesia di tengah pandemi Covid-19 mengalami penurunan. Hal ini salah satunya dikarenakan berkurangnya aktivitas masyarakat secara drastis yang memengaruhi laju pertumbuhan ekonomi (Widiastuti \& Silfiana, 2021). 


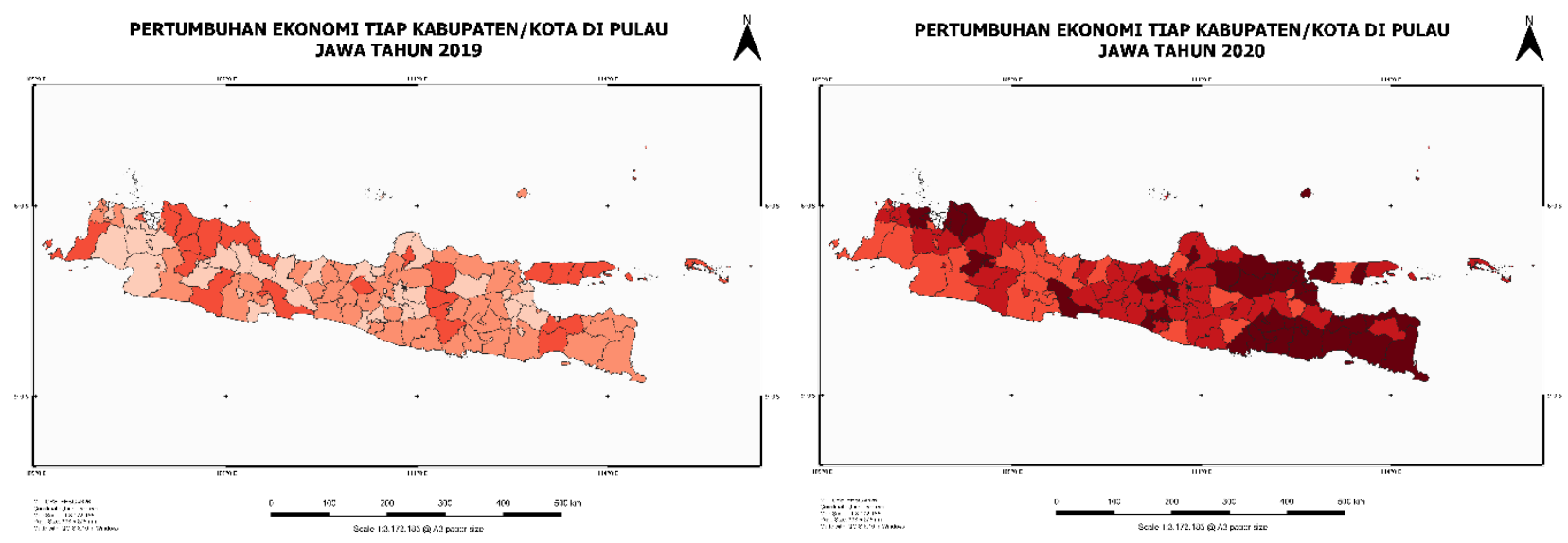

Keterangan:

$\begin{array}{ll}\square \text { Bukan Daerah Cakupan } & -1,13-5,05 \\ -11--2,08 & 5,05-5,68 \\ -2,08--1,13 & 5,68-15\end{array}$

Gambar 4. Pertumbuhan Ekonomi Tiap Kabupaten/Kota di Pulau Jawa Tahun 2019 dan 2020

Dari Gambar 4, dapat dilihat bahwa terjadi penurunan pertumbuhan ekonomi yang cukup signifikan dari tahun 2019 ke tahun 2020. Pada tahun 2019, rata-rata laju pertumbuhan ekonomi kelima provinsi di Pulau Jawa memiliki nilai di atas 5\%, yaitu 5,46\%. Sementara itu, pada tahun 2020 hampir seluruh seluruh kabupaten/kota di Pulau Jawa memiliki nilai pertumbuhan ekonomi yang negatif dan rata-rata seluruh kabupaten/kotanya turun hingga -2,13\%. Menurut Alwandi dan Muchlisoh (2020), sektor ekonomi terkontraksi cukup dalam setelah memasuki pandemi COVID-19 khususnya pada wilayah yang kegiatan perekonomiannya berbasis industri pengolahan dan perdagangan. Setelah dilakukan pengolahan LQ dan MRP, serta penentuan sektor unggulan pada tiap kabupaten/kota di Pulau Jawa, diketahui bahwa secara rata-rata, terdapat 3-4 sektor unggulan tiap kabupaten/kota di Pulau Jawa pada tahun 2019 dan 2-3 sektor unggulan pada tahun 2020.

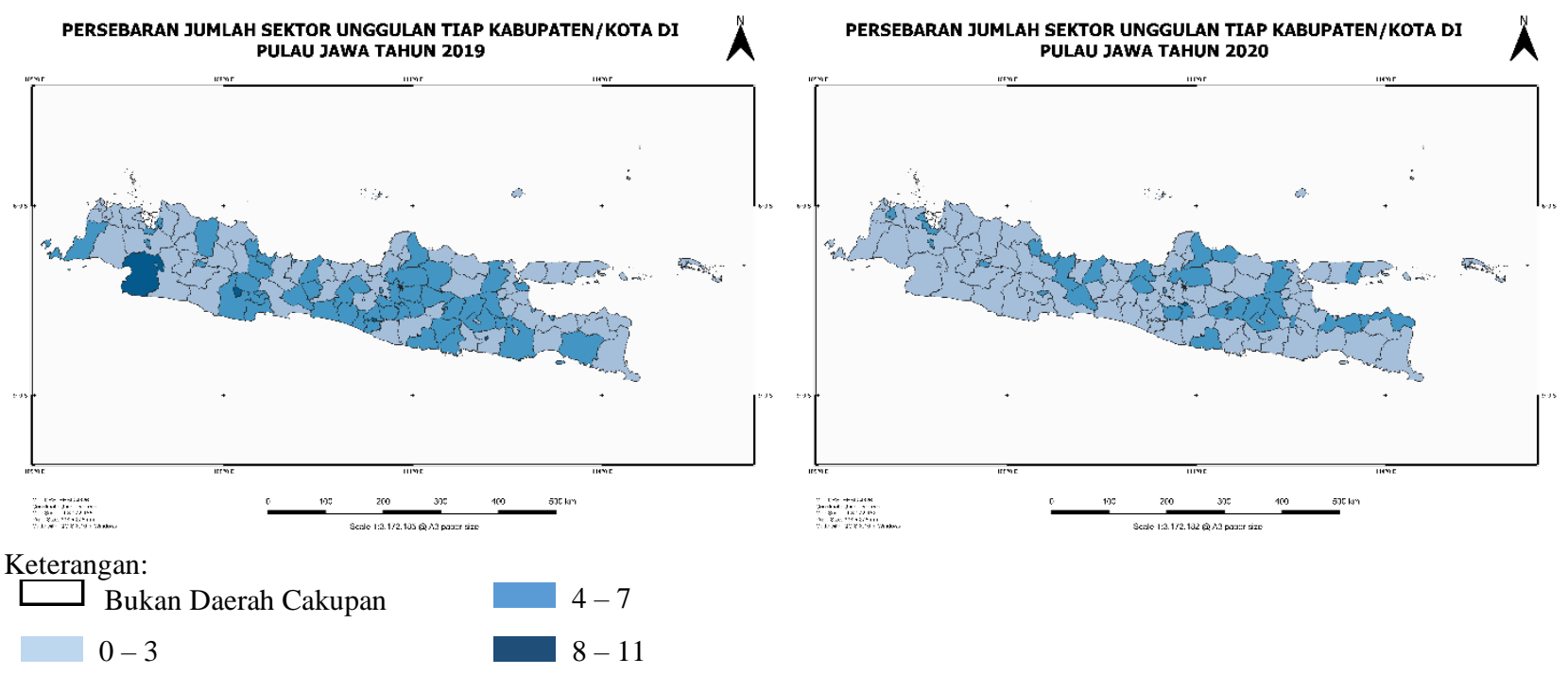

Gambar 5. Persebaran Jumlah Sektor Unggulan Tahun 2019 dan 2020

Gambar 5 menunjukkan persebaran jumlah sektor unggulan dari kedua tahun. Terjadi perubahan jumlah sektor unggulan secara rata-rata menjadi lebih rendah di kebanyakan kabupaten/kota Pulau Jawa pada tahun 2020. Wilayah yang pada tahun 2020 masih memiliki sektor unggulan relatif tinggi adalah Kota Bandung, Kota Surakarta, dan Kota Batu. Berdasarkan hasil analisis, pada tahun 2020, sektor lapangan usaha yang pertumbuhannya paling menonjol di Kota Bandung adalah sektor Transportasi dan Pergudangan dan sektor Jasa Lainnya, Kota Surakarta dengan sektor Pertambangan dan Penggalian dan sektor Jasa Pendidikan, dan Kota Batu dengan sektor Administrasi Pemerintahan dan sektor Penyediaan Akomodasi dan Makan Minum. 




(a) Pertumbuhan Ekonomi

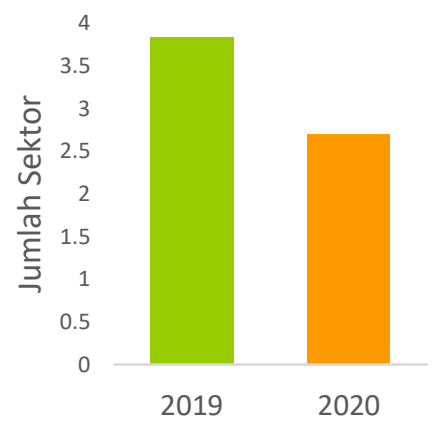

(d) Jumlah Sektor Unggulan

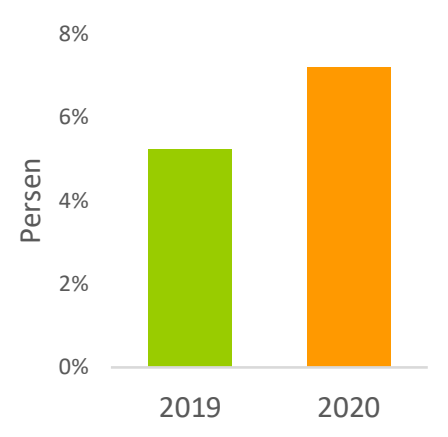

(b) Tingkat Pengangguran Terbuka

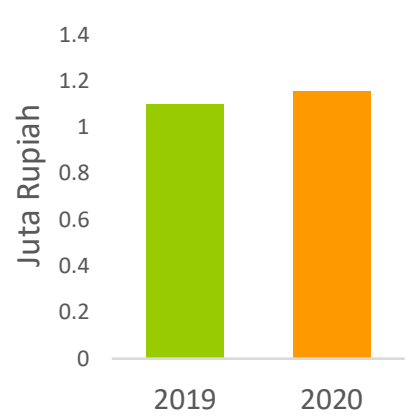

(e) Pengeluaran per Kapita

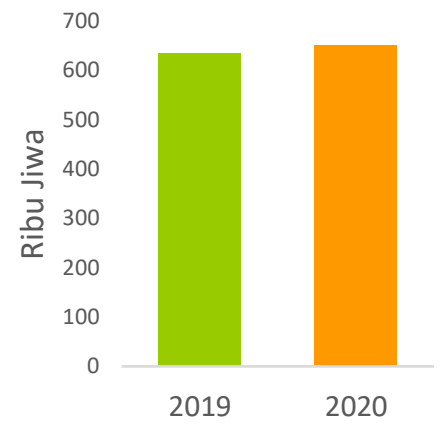

(c) Angkatan Kerja

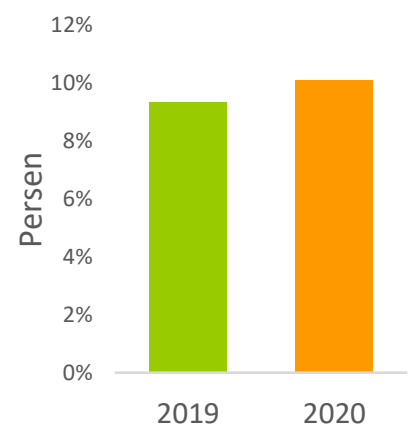

(f) Persentase Penduduk Miskin

Gambar 6. Perbandingan Variabel Sosial Ekonomi di Pulau Jawa Tahun 2019 dan 2020

Perubahan pertumbuhan ekonomi menjadi lebih rendah dan perubahan jumlah sektor unggulan dapat mengindikasikan bahwa fenomena yang terjadi pada tahun 2020, yaitu pandemi Covid-19, berpengaruh terhadap kondisi dan perubahan struktur perekonomian di seluruh kabupaten/kota di Pulau Jawa. Gambar 6 menunjukkan bahwa variabel pertumbuhan ekonomi dan sektor unggulan pada tahun 2020 mengalami penurunan. Sementara itu, variabel lainnya, yaitu Tingkat Pengangguran Terbuka, persentase penduduk miskin, jumlah angkatan kerja, dan rata-rata pengeluaran per kapita, mengalami kenaikan. United Nations Industrial Development Organization (2020) dalam penemuannya didapat bahwa pandemi Covid-19 memberikan dampak ekonomi pada pembangunan manusia, perdagangan global, tingkat pengangguran, kemiskinan, krisis ekonomi, serta penurunan kinerja sektor lapangan usaha (Rachmawati et al, 2020).

\section{Evaluasi Pengelompokan}

Evaluasi atau validasi pengelompokan untuk menentukan jumlah klaster terbaik yang digunakan dalam penelitian ini adalah Indeks Davies-Bouldin (DB), Indeks Calinski-Harabasz (CH), dan Indeks Xie-Beni. Jumlah $\mathrm{k}$ yang dipilih dalam penelitian ini adalah dari 3 hingga 6 klaster. Berikut merupakan hasil evaluasi dari tiap indeks pada kedua tahun penelitian.

Tabel 1. Evaluasi Hasil Pengelompokan Tahun 2019

\begin{tabular}{cccc}
\hline Jumlah Klaster & Davies Bouldin & Calinski Harabasz & Xie Beni \\
\hline$(1)$ & $(2)$ & $(3)$ & $(4)$ \\
\hline 3 & $\mathbf{2 , 1 1}$ & $\mathbf{2 1 , 9 2}$ & 19,05 \\
4 & 3,09 & 15,89 & 18,53 \\
5 & 2,71 & 19,43 & 15,49 \\
6 & 2,55 & 17,88 & $\mathbf{6 , 5 8}$ \\
\hline
\end{tabular}


Tabel 2. Evaluasi Hasil Pengelompokan Tahun 2020

\begin{tabular}{cccc}
\hline Jumlah Klaster & Davies Bouldin & Calinski Harabasz & Xie Beni \\
\hline$(1)$ & $(2)$ & $(3)$ & $(4)$ \\
\hline 3 & 1,55 & $\mathbf{3 2 , 7 2}$ & 7,22 \\
4 & 1,73 & 27,44 & 8,61 \\
5 & $\mathbf{1 , 1 1}$ & 29,54 & $\mathbf{3 , 0 7}$ \\
6 & 1,27 & 29,96 & 5,56 \\
\hline
\end{tabular}

Berdasarkan hasil evaluasi pada Tabel 3 dan 4, jumlah klaster terbaik untuk tahun 2019 merupakan 3 klaster yang memiliki dua dari tiga indeks dengan nilai terbaik. Sementara, untuk tahun 2020, berdasarkan hasil evaluasi didapat jumlah klaster terbaik merupakan 5 klaster dengan dua dari tiga indeks terbaik.

\section{Karakteristik Hasil Pengelompokan Tahun 2019 dan 2020}

Berdasarkan hasil evaluasi pengelompokan, diperoleh sebanyak 3 klaster untuk tahun 2019 yang dapat menggambarkan kondisi sosial ekonomi sebelum memasuki pandemi COVID-19 dan 5 klaster pada tahun 2020 yang dapat menggambarkan kondisi sosial ekonomi setelah memasuki pandemi COVID-19. Diagram radar menunjukkan perbedaan karakteristik tiap klaster menurut nilai rata-rata tiap variabel setiap tahunnya secara terpisah.

Berdasarkan Gambar 7 dan 8, dapat dilihat persebaran anggota untuk tiap klaster pada tahun 2019 dan tahun 2020. Secara umum, pola persebaran untuk klaster 1, 2, dan 3 tidak jauh berbeda, walaupun terdapat beberapa kabupaten/kota yang mengalami perubahan keanggotaan klaster. Dapat dilihat pula pada tahun 2020 terdapat 2 klaster yang baru terbentuk. Hal ini mengindikasikan terdapat perubahan karakteristik sosial ekonomi antara tahun 2019 dan 2020.
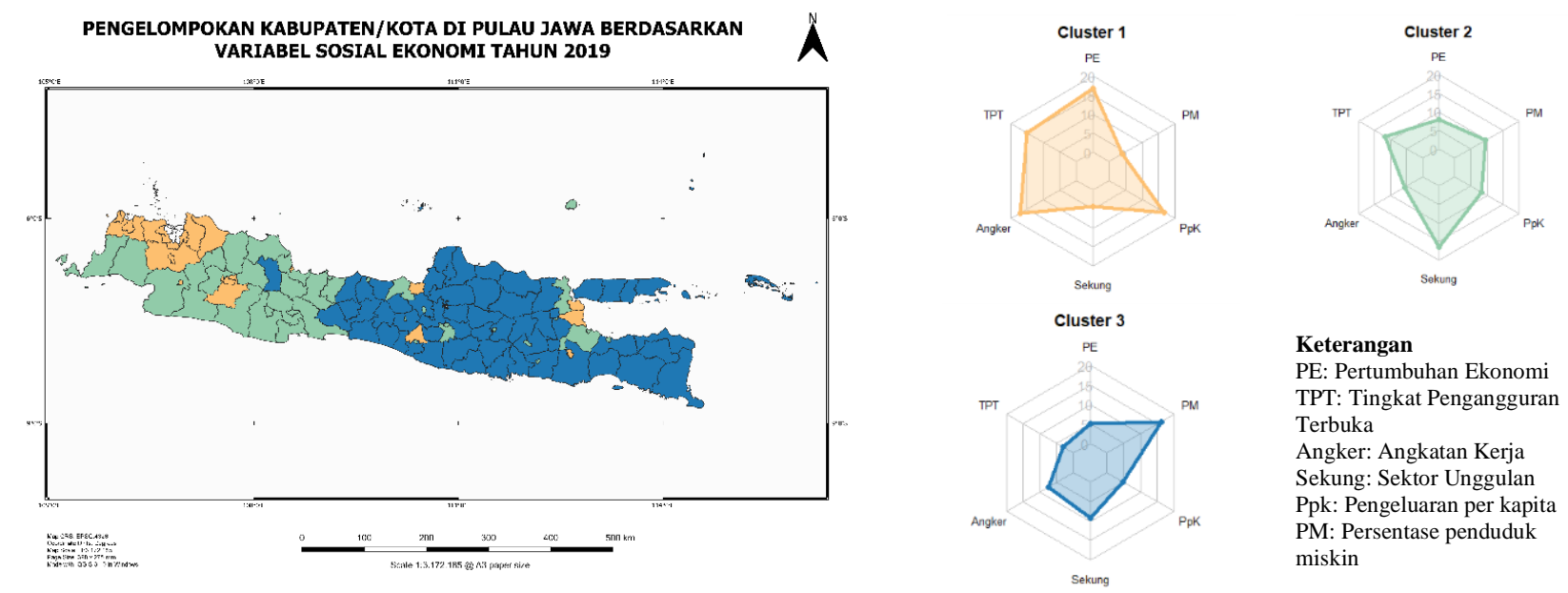

Gambar 7. Pemetaan Hasil Klaster dan Radar Plot Tahun 2019 


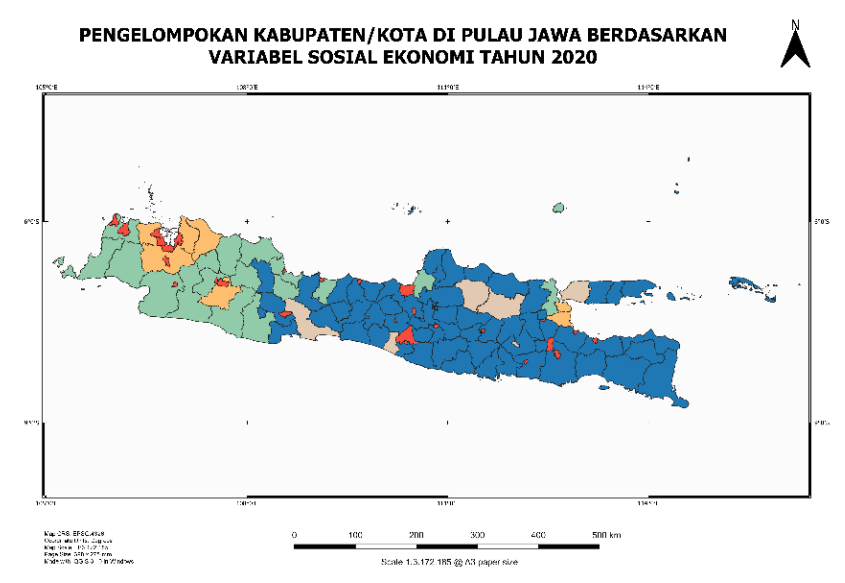

Gambar 8. Pemetaan Hasil Klaster dan Radar Plot Tahun 2020

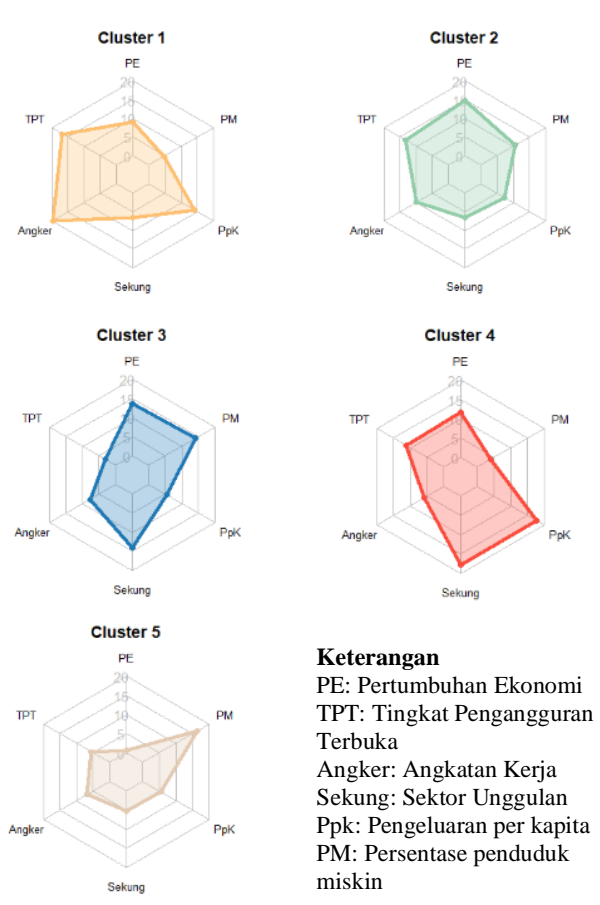

Secara lebih rinci, sebagian besar anggota klaster 1 untuk kedua tahun tersebar di sekitar DKI Jakarta. Jika dibandingkan dengan klaster lainnya untuk setiap tahun, karakteristik dari variabelnya pun memiliki kemiripan, yaitu dicirikan dengan nilai rata-rata variabel yang relatif tinggi pada variabel tingkat pengangguran, jumlah angkatan kerja, dan pengeluaran per kapita. Namun, pertumbuhan ekonomi klaster 1 pada tahun 2020 relatif rendah dibandingkan klaster lainnya. Berbeda dengan tahun 2019 yang jika dibandingkan klaster lainnya, pertumbuhan ekonomi klaster 1 relatif tinggi. Hal ini salah satunya dikarenakan pembentukan klaster baru pada tahun 2020 sehingga terjadi perpindahan anggota dari klaster 1. Dominasi jumlah sektor unggulan juga mengalami perubahan yang pada tahun 2019 dicirikan dengan sektor jasa keuangan dan asuransi menjadi sektor informasi dan komunikasi pada tahun 2020.

Klaster 2 sebagian besar tersebar di Provinsi Banten dan Jawa Barat, baik untuk tahun 2019 maupun 2020. Namun, terdapat perpindahan beberapa anggota, khususnya di perbatasan Jawa Barat dan Jawa Tengah, menjadi ke klaster 3 pada tahun 2020. Pada tahun 2019, klaster 2 memiliki jumlah sektor unggulan yang relatif lebih banyak dibandingkan klaster lainnya, namun pada tahun 2020 menjadi relatif sedikit dibandingkan klaster lain. Pada tahun 2020, anggota klaster 2 memiliki rata-rata pertumbuhan ekonomi yang relatif tinggi dibandingkan klaster lainnya. Hal ini mengindikasikan bahwa anggota klaster 2 lebih resisten terhadap kontraksi ekonomi setelah memasuki pandemi COVID-19. Sektor pertanian menjadi sektor unggulan yang mendominasi pada tahun 2020.

Pada tahun 2019, klaster 3 dicirikan dengan anggota kelompoknya yang memiliki persentase penduduk miskin relatif tinggi. Baik tahun 2019 maupun 2020, sebagian besar anggota klaster 3 tersebar di D. I. Yogyakarta, Jawa Tengah, dan Jawa Timur. Berdasarkan dominasi sektor unggulannya, terjadi perubahan dari kedua tahun, pada tahun 2019 sektor unggulan yang mendominasi adalah sektor pertanian, sementara pada tahun 2020 adalah sektor administrasi pemerintahan serta sektor jasa kesehatan dan kegiatan sosial.

Klaster 4 dan 5 merupakan klaster yang pada tahun 2019 tidak terbentuk. Dominasi anggota klaster 4 merupakan anggota dari klaster 1 pada tahun 2019, dan tersebar di seluruh Pulau Jawa yang dicirikan dengan nilai rata-rata jumlah sektor unggulan dan pertumbuhan ekonomi yang relatif tinggi, namun pengeluaran per kapita dan tingkat penganggurannya relatif tinggi pula. Dari 27 anggota klaster 4, hanya 1 anggota yang merupakan kabupaten. Murapi et al (2021) dan Syahrial (2020) dalam penelitiannya menyampaikan bahwa penduduk di daerah perkotaan memiliki tantangan yang lebih berat dan rentan terkena dampak pemutusan kerja akibat Covid-19. Hal ini kemudian berimbas pada peningkatan tingkat pengangguran. Selain itu, pengeluaran per kapita pun relatif lebih tinggi di daerah perkotaan. Sejalan dengan hasil Survei Sosial Ekonomi Nasional (SUSENAS) Maret 2016, terdapat perbedaan yang cukup tinggi antara perkotaan dan pedesaan untuk rata-rata pengeluaran per kapita sebulan.

Klaster 5 merupakan klaster dengan anggota paling sedikit dibandingkan 4 klaster lainnya pada tahun 2020, yaitu sebanyak 6 kabupaten/kota, dan tersebar di Provinsi Jawa Tengah, D. I. Yogyakarta, dan Jawa 
Timur. Klaster ini diindikasikan paling terdampak secara sosial ekonomi akibat pandemi pada tahun 2020, dengan dicirikan memiliki nilai rata-rata variabel pertumbuhan ekonomi yang terendah dan penduduk miskin tertinggi dibandingkan 4 klaster lainnya. Rahmawati et al (2021) dalam penelitiannya menyampaikan bahwa dampak dari terganggunya kegiatan perekonomian akibat pandemi COVID-19 menyebabkan peningkatan tingkat kemiskinan secara signifikan di Provinsi Jawa Timur. Thaariq et al (2020) menyampaikan bahwa Jawa Timur dan Jawa Tengah termasuk dalam provinsi dengan jumlah orang miskin multidimensi terbanyak di Pulau Jawa. Berdasarkan dominasi sektor unggulannya, didapat bahwa klaster ini hanya memiliki jumlah sektor unggulan maksimal 1, yaitu untuk sektor pertambangan dan penggalian, sektor jasa keuangan dan asuransi, sektor jasa pendidikan, dan sektor jasa lainnya.

Berdasarkan hasil analisis klaster yang terbentuk, terlihat bahwa antar klaster tiap tahun memiliki ciri-ciri yang berbeda, begitu pula dengan pembentukan klaster antar tahun. Perbedaan ini tidak menunjukkan perbandingan perubahan variabel-variabel secara langsung dari kedua tahun baik melalui radar plot maupun tabel nilai karakteristik dikarenakan pengelompokan dilakukan secara independen/terpisah.

\section{KESIMPULAN}

Berdasarkan hasil penelitian yang didapatkan, dapat disimpulkan bahwa kondisi sosial ekonomi di Pulau Jawa secara umum mengalami perubahan karakteristik, dilihat dari jumlah klaster terbaik yang terbentuk yang pada tahun 2019 sebanyak 3 klaster menjadi sebanyak 5 klaster pada tahun 2020, serta perubahan nilai ratarata variabel tiap klaster melalui diagram radar. Selain itu, terjadi pergeseran sektor unggulan di Pulau Jawa setelah memasuki pandemi COVID-19. Klaster 5 diindikasikan paling terdampak secara sosial ekonomi pada tahun 2020, ditandai dengan sebagian besar indikator sosial ekonomi memiliki kinerja yang kurang baik seperti rendahnya pertumbuhan ekonomi dan sektor unggulan serta tingginya persentase penduduk miskin. Klaster tersebut memuat 6 kabupaten/kota, yaitu Kab. Cilacap, Kab. Blora, Kab. Kulon Progo, Kab. Bojonegoro, Kab. Bangkalan, dan Kota Kediri, yang memiliki sektor unggulan pada sektor pertambangan dan penggalian, serta sektor-sektor jasa. Di sisi lain, klaster 2 yang anggotanya sebagian besar di Banten dan Jawa Barat diindikasikan lebih resisten karena memiliki rata-rata pertumbuhan ekonomi yang relatif tinggi dibandingkan klaster lainnya, memiliki dominasi sektor unggulan yang salah satunya pada sektor pertanian.

\section{DAFTAR PUSTAKA}

Alwandi, M. A., \& Muchlisoh, S. (2020). Karakteristik Pertumbuhan Ekonomi Dan Sektor Basis Provinsi Di Indonesia Pada Masa Pandemi Covid-19. In Seminar Nasional Official Statistics (Vol. 2020, No. 1, pp. 82-90).

COVID-19, G. T. P. P. (2020). Peta Sebaran | Gugus Tugas Percepatan Penanganan COVID-19. Covid19.Go.id. https://covid19.go.id/peta-sebaran

Glasson, J., \& Marshall, T. (2007). Regional planning. Routledge.

Indonesia Economic Prospects, July 2020: The long road to recovery. (2020, July 16). World Bank. https://www.worldbank.org/en/country/indonesia/publication/july-2020-indonesia-economic-prospect

Hair, et al. (2019). Multivariate Data Analysis. Cengage Learning Emea. Copyright.

Iam-on N, Garret S. 2010. LinkCluE: A MATLAB Package for Link-Based Cluster Ensemble. Journal of Statistical Software. 36(9):1-3

M Ikhsan Modjo. (2020). Memetakan Jalan Penguatan Ekonomi Pasca Pandemi. Jurnal Perencanaan Pembangunan: The Indonesian Journal of Development Planning, 4(2), 103-116. https://doi.org/10.36574/jpp.v4i2.117

Murapi, I., Astarini, D. A. O., \& Subudiartha, I. N. Tingkat Pengangguran Akibat Covid-19 di Provinsi Nusa Tenggara Barat.

Olivia, S., Gibson, J., \& Nasrudin, R. (2020). Indonesia in the Time of Covid-19. Bulletin of Indonesian Economic Studies, 56(2), 143-174. doi:10.1080/00074918.2020.1798581

Rachmawati, L., Cahyono, H., Nugraha, J., Watjuba, L., \& Hanifa, N. (2020). Shift Share analysis Indonesia masa pandemi Covid-19. Jurnal Ekonomi Modernisasi, 16(3), 165-178.

Rahmawati, A., Lutfiani, L., Yunia, Z. R., Rofiqoh, I., Zahrok, F. F., \& Wahyuningtyas, D. (2021). Dampak Pandemic Covid- 19 Terhadap Indeks Pembangunan Ekonomi Inklusif Jawa Timur Indikator Tingkat Kemiskinan Dan Ketimpangan. Efektor, 8(1), 79-88. https://doi.org/10.29407/e.v8i1.15708

Saeed, F., Salim, N., Abdo, A., \& Hentabli, H. (2012, December). Combining multiple individual clusterings of chemical structures using cluster-based similarity partitioning algorithm. In International Conference 
on Advanced Machine Learning Technologies and Applications (pp. 276-284). Springer, Berlin, Heidelberg.

Strehl, A., \& Ghosh, J. (2002). Cluster ensembles---a knowledge reuse framework for combining multiple partitions. Journal of machine learning research, 3(Dec), 583-617.

Stukalo, N., \& Simakhova, A. (2018). Global parameters of social economy clustering. Problems and Perspectives in Management, 16(1), 36-47. https://doi.org/10.21511/ppm.16(1).2018.04

Syahrial, S. (2020). Dampak COVID-19 terhadap Tenaga Kerja di Indonesia. Jurnal Ners, 4(2), 21-29.

Thaariq, Rahmanda M., et al. (2020). "Prakarsa Working Paper 01 - Multidimensional Poverty and the Risk of COVID-19 in Indonesia ." Perkumpulan Prakarsa, 2020.

Widiastuti, A., \& Silfiana, S. (2021). Dampak Pandemi Covid-19 Terhadap Pertumbuhan Ekonomi Di Pulau Jawa. Jurnal Ekonomi-Qu, 11(1), 97-107. 